\title{
Understanding change in higher education as bricolage: How academics engage in curriculum change Severine Louvel
}

\author{
To cite this article \\ Séverine Louvel. Understanding change in higher education as bricolage: how \\ academics engage in curriculum change. Higher Education, Springer Verlag, 2013, 66 \\ (6), pp.669-691.
}

\begin{abstract}
The engagement of academics in organizational change in higher education institutions is generally understood as involving a wide range of behaviors, and previous studies have situated academics' actions at various points along a continuum between passivity and proactivity. This article complements this approach by asking how - rather than in which contexts - academics act as central agents for change in higher education. Rather than trying to assess their global level of proactivity in a given change situation, we aim at identifying the actions which show them behaving more or less strategically. We argue that the notion of 'bricolage' - widely used in organization theory - can be useful in this respect. Based on a qualitative study of the creation of 20 post-graduate nanotechnology programs on French university campuses, the article shows that academics participating in curriculum change engage in three distinct forms of bricolage. We suggest that the bricolage lens can identify two types of actions via which academics implement more or less pro-active strategies identifying a repertoire of resources, and assembling those resources - and so allows us to reflect more deeply on how these actions may demonstrate several forms of agency, as well as several different relationships with norms, in each organizational change situation.
\end{abstract}

Key words

Academics, bricolage, organizational change, strategies in higher education, nanotechnology 


\section{Introduction}

Higher education has long been described as being stable and conservative - even as suffering from "institutional sclerosis" (Maassen and Gornitzka 1999) - and scholars have analyzed the factors limiting organizational change in higher education institutions, and how academics respond - or contribute - to such limitations. This work has positioned their attitudes towards organizational change along a continuum (Huisman and Meek 1999) ranging from passivity and compliance to norms (DiMaggio and Powell 1983) to more proactive stances (Weick 1976). But this approach - while very useful - has been criticized, especially as the norms to which academics are required to respond often derive from several sources, and so their strategies may be plural and at times even inconsistent.

In this paper, we do not ask in what contexts do academics behave as effective and central agents of organizational change in higher education, but rather how they contribute to such change, regardless of the constraints they face or the norms they respond to - with what capacity for action and employing what strategies. We assume that any change situation enables academics to exert a certain level of strategic behavior. But instead of trying to assess their overall level of proactivity in any given change situation, we are interested in identifying the change actions which show academics behaving more or less strategically. To analyze the mix of compliance and self-determination with which academics contribute to organizational change, we adopt the notion of 'bricolage', as used in organization studies in general and in entrepreneurial studies in particular (Duymedjian and Rüling 2010). These studies define bricolage as a regime of activity in which change and innovation are both creative and highly constrained, and where individuals or groups create something new out of the resources they have at hand - while they still respect certain rules or conventions, they don't follow any strictly predetermined plan. We show how the bricolage concept draws our attention to two dimensions of action via which they adopt more or less pro-active strategies: how they identify existing resources (the 'repertoire'), and how they assemble those resources.

Our study analyzes curriculum change in higher education - a type of organizational change that is central to that context - and looks at how teams of academics transform existing curricula or create new ones. Our analysis is based on a qualitative study of the creation of 20 post-graduate nanotechnology programs at three French university campuses between 2002 and 2010. Nanotechnology education expanded considerably during this period in French higher education (from 20 to 90 programs), and represents an interesting field of inquiry which both faces academics with various budgetary and institutional constraints but at the same time offers them significant professional opportunities.

This article is organized as follows. First the literature review outlines the research that has considered academics' capacity to engage strategically in organizational change, shows how the notion of bricolage is a useful complement to this literature, and presents some background information on curriculum change in French higher education. The method section explains why nanotechnology training programs represent an interesting area of study and provides a detailed account of the field work conducted for this study. The results section shows that academics' engagement in curriculum change can be described as a bricolage 
activity, analyses the three different forms of this activity we observed in our case study, and specifies the actions in which academics behave more or less strategically. Finally, the conclusion returns to the relevance of the bricolage notion for analyzing academics' individual and collective strategies to transform their organizations.

\section{Literature review}

\section{1. Are academics central agents for change in higher education?}

Higher education is considered as being a generally conservative field in many respects, and seminal work has highlighted the barriers that prevent academics from actively participating in organizational change at universities. Some authors follow DiMaggio and Powell's (1983) definition of higher education as a domain that combines three mechanisms of institutional isomorphism - coercion (universities' missions are prescribed in law); mimetic behaviors (a frequent response to problems with ambiguous causes or unclear solutions (p.151)); and finally the normative pressures imposed by the academic professions, which emphasize the need to follow pre-existing standards, rules or models and strongly limit the range of organizational change academics can envision: "These organizations are highly effective at 'professional' innovation - updating the field within existing disciplinary fields [...] creating new pigeon holes. Professors may make advances within individual units, but the institution as a whole does not experience radical change" (Hardy 1991, p.369). Other authors align with Weick's (1976) definition of education as a 'loosely coupled' system, linking conservatism within higher education to the characteristics of knowledge production. Only specialists within the same subject can agree on the means, objectives and criteria for evaluating research and teaching outcomes (Clark 1983), which may justify the collegial governance of universities (Musselin 2004), but also explains the difficulty higher education institutions have in transforming themselves in comprehensive and consistent ways. Bleiklie and Michelsen (2008) argue that academics consider the university "as an arena rather than an organizational actor" (p.58), and other authors show that they are likely to react to any reform driven by their management by "ritualized conformity" (Meyer and Rowan 1977; Townley 1997) - but without necessarily changing much in terms of their actual practices.

Further work has complicated this initial picture of academics' engagement in organizational change. Organizational change has become somewhat of a 'slogan' in higher education since the 1980s, with universities being encouraged to transform themselves into "organizational actors" (Brunsson and Sahlin-Anderson 2000), endowed with individual identities, hierarchies and strategic capacities. University managers have gained extended powers, and adopted business methods to implement organizational change, with a consequent tendency to 'managerialism' (Amaral 2008). The scope and depth of organizational change varies greatly from one higher education institution to another, with the pressure and capacity for change depending on ecological factors (such as size or geographic localization) (Brint et al. 2011), and on political and governance issues (Fumasoli and Lepori 2011).

In this context, several studies have analyzed how academics experience the pressures for organizational change exerted by new actors in university governance - such as governments, 
university managers, student bodies, and firms (Enders et al. 2008) - and how they respond to them. Academics are encouraged (or forced) to adopt certain standards for their research and teaching activities, and to try to acquire certain resources (e.g. via private funding, international collaborations) to support them. Their engagement in organizational change has been analyzed as being more or less conformist in attitude. For instance, some academics may respond to the rise of the audit culture at universities (Shore and Wright 2000) by 'window-dressing', whereas others may engage with their university managers less defensively in co-constructing change strategies in their departments (Hardy 1991; Gioia and Thomas 1996; Townley 1997; Jarzabkowski 2008; Fumasoli and Lepori 2011).

Several authors (Huisman and Meek 1999; Maassen and Gornitzka 1999; Maassen 2002; Leisyte et al. 2008; Reale and Seeber 2011) have analyzed academics' responses using Oliver's (1991) typology, which is composed of five strategies (acquiescence, compromise, avoidance, defiance, and manipulation) varying in active agency "from passivity to increasingly active resistance" (p.151). However, Oliver's typology has been criticized as being too simplistic - one of its difficulties is that her characterization of the pressures that guide academics' actions distinguishes between two kinds of environments that exert different sorts of pressures: the "institutional environment" (composed of "those who shape and enforce institutional rules and beliefs" (Oliver 1991 p.148) such as regulatory structures, governmental agencies, and laws), and the "task environment" (composed of "those who control scare resources" (p.148)). However, in practice, this distinction is often blurred - as Reale and Seeber (2011) note: "an evaluation process, for instance, may influence both resource flow and scientific reputation" (p.5), nor are the pressures always clearly defined (Fumasoli and Lepori 2011), while the institutions exerting them are rarely monolithic: "institutional environments are pluralistic, offering multiple sources of what constitutes legitimate practice" (Townley 1997 p.263). These limitations may explain why certain organizational change situations (such as the creation of new curricula) see academics combining apparently contradictory strategies, such as acquiescence and avoidance (Huisman and Meek 1999).

We argue that asking a slightly different question could refresh the analysis of academics' strategic behavior in change situations. In contrast to previous studies, we are not primarily interested in examining what institutional conditions lead academics to act as effective and strategic agents of organizational change in higher education, or in assessing their overall degree of proactivity in a given context. Assuming that any change situation - even the most constrained - will leave academics with a certain amount of room for maneuver, our purpose is rather to understand how they actually contribute to such change, and what their strategic behavior consists of. We explain why the notion of 'bricolage', originally expounded by Lévi-Strauss (1966), and widely used since in organization studies (Baker and Nelson 2005; Duymedjian and Rüling 2010; Odin and Thudéroz, 2010), is relevant to identifying the kind of actions via which academics implement more or less pro-active strategies - and thus articulate pro-activity and compliance, creativity and conformity - when engaging in organizational change. 


\section{2. Understanding academics' engagement in organizational change as bricolage}

C. Lévi-Strauss' (1966) 'bricolage' concept starts from contrasting how the 'engineer' and the 'bricoleur' engage in their activities. The former first assesses the problem and then gathers the resources they expect to need to create a solution, trying to follow a plan or to meet predefined performance criteria. By contrast, the latter creates something new out of resources they have (or can find) at hand, establishes their usefulness by combining them, and discovers the solution's functionalities during the creation process. The notion of "bricolage" has recently become quite popular in organizational theory in general (Duymedjan and Rüling 2010; Odin and Thudéroz, 2010), and in the literature on entrepreneurship in particular (Baker et al. 2003; Garud and Karnøe 2003; Baker and Nelson 2005). While the idea is especially relevant in understanding how some entrepreneurs act in resourceconstrained environments (Baker and Nelson 2005), it is not intrinsically associated with a shortage of resources: rather, what differentiates the bricoleur from the engineer is not so much the amount of resources at their disposal, as how they employ them in their activities. The 'bricoleur' and the 'engineer' are ideal-types - as such, they are rarely seen in their pure forms in reality - but they are useful to reflect how different organizational actors design and execute solutions in their environments. In a sense, these ideal-types can be seen as two opposite reactions to the restraints that the "bounded rationality" of individuals and organizations places on action (Simon 1972; March 1978) - namely, the inability to identify and to assess all alternatives, and thus to determine optimal solutions. Faced with this uncertainty, the 'engineer' nevertheless still tries to follow some general 'plan' which specifies which kind of resources to seek for, and how to make use of them, hoping to come as close as possible to some abstract ideal - even though it is almost never fully reached in practice, as objectives are abandoned or redefined along the way, and engineers may follow "satisficing rules for decision making" (March 1978 p.594) and so stop searching before reaching the optimal solution. The 'bricoleur', too, can also be said to be unable to find the 'one best way', the optimal solution - but (unlike the engineer) they do not rely on a predesigned model to define their course of action. This is not to say their creation process unfolds randomly, but rather that its objectives may be rather vague at the beginning, but gradually become more defined as resources are gathered. Primarily, the project relies on the resources they have at hand, and solutions and their functionalities emerge from the various combinations which they try out in their creation processes.

Three elements are important in analyzing bricolage as a specific regime of action (Duymedjan and Rüling 2010). First, the 'repertoire' - the range of material and non-material resources actors have at hand for their bricolage activity, but which have not necessarily been collected for that specific purpose. Bricoleurs "thrive on low functional fixedness of resources" (p.143) i.e., that resources are not necessarily limited to particular uses - and so can be used for different - not predefined - purposes, whereas engineers collect specific resources for known future needs. Individuals' personal and professional networks can often constitute or provide such bricolage 'repertoire' items, which can be 'activated' when needed. Baker et al (2003) label the "dependence on pre-existing contact networks as the means at hand" (p.265) as "network bricolage", and contrast it to resource-seeking behavior ("attempting to find new useful network contacts" p.265). Second, the process of bricolage 
itself consists of combining elements from the repertoire (permuting or substituting them where necessary) into an 'assemblage' that follows certain rules, and which promises to offer a solution: "For the bricoleur, the value of an object is not determined by its intrinsic value, or by market structures, but in terms of a particular arrangement" (Duymedjan and Rüling 2010 p.146). Lastly, bricolage activities are usually 'one-offs' - particular solutions able to address specific problems - rather than being intended to yield long-lasting generic patterns that can be copied across to other contexts. As such they may be rather 'makeshift' in nature a fact that their 'bricoleurs' may need to conceal, perhaps in the interest of gaining legitimacy for their efforts.

To sum up, bricoleurs may act in different social worlds (e.g. administrative, artistic, industrial), but show creativity in fashioning solutions from a (perhaps limited) set of available resources (Odin and Thudéroz 2010). The constraints on bricolage are the contents of the repertoire, and the limited number of possible ways in which those elements can be combined. But bricolage is a creative activity, leading to a new and unique assemblage, one which can only be reproduced with extreme difficulty - this element of creativity is what explains why different actors can generate heterogeneous value from identical resources (Baker and Nelson 2005 p.330).

We see the bricolage 'lens' as being useful in viewing the multiple ways in which academics engage in organizational change. Indeed, universities seem to be favorable settings for enacting bricolage-type actions. First, they have been characterized as organizations with "multiple goals" and "unclear technologies", where univocal relationships between means and ends are difficult to establish (Cohen et al. 1972 cited by Musselin 2004 p.108). In this type of organization, the 'engineer'-type pattern of action can be difficult to adopt, as academics cannot rely on any predefined formula to conduct their projects. Second, an academic resource (a colleague, a course, a piece of equipment) can be described as having a "low functional fixedness", and as being potentially useful for several purposes. One should therefore expect academics to act as bricoleurs in assembling multiple projects from what they have at hand, and to try out several resource combinations to change their organizations.

We next present some background information on curriculum change in French higher education. Because of the mix of strategies (conformity with norms and standards, alignment with institutional strategies, negotiation with various stakeholders, proactivity in pursuing professional interests) which characterize French academics' engagement in curriculum change, these change situations provide a particularly interesting setting in which to analyze what the bricolage notion brings to the understanding of academics' strategic behavior in higher education.

\subsection{Curriculum change in French higher education}

The government is a key player in curriculum change in French universities. French higher education is publicly funded (up to $85 \%$ of all students' costs), and all university degrees are accredited by the Ministry for Higher Education (this 'habilitation' is granted for four years). 
Since France joined the Bologna process ${ }^{1}$, university programs no longer follow national patterns ('maquettes') designed by the Ministry, although informal ministerial guidelines (for example, for the approximate number of teaching hours for masters' programs) are still in effect. Over the last decade, the French Higher Education Ministry has also sought to strengthen universities' ability to manage curricular change and design program courses and encouraged them to actively structure coherent supply programs. Keen to raise their low international visibility and to reduce their costs, universities increasingly encourage departments to rationalize their supply of programs and courses (by merging duplicated courses and closing less attractive programs). To sum up, the engagement of academics in curriculum change within French universities has, broadly, evolved in recent years from a situation of academic departments complying with ministerial rules, to them engaging with their university management in negotiating processes, and having to align with overall institutional strategies (Witte 2009 p.237), with potential tensions for their professional aspirations.

Curriculum change unfolds differently in French non-university higher education, particularly because French engineering schools - which play a central role in the country's science and technology training - have their own accreditation system. Program accreditations are issued every six years by the CTI (Commission des Titres pour l'Ingénieur, an independent body acting on behalf of the Ministry and made up of representatives from academia and industry) which sets course standards (for instance, specifying the balance of different disciplines to be included). Moreover, the heads of engineering schools set strategic directions which take direct account of the needs of the firms which subsidize students' training and later employ the schools' graduates. The situation at French engineering schools can thus generally be described as departments complying with CTI standards and their schools' management strategies, and finding compromises with external stakeholders (including industrial firms).

\section{Method}

\section{1. The creation of post-graduate nanotechnology programs}

Nanotechnology refers to "the understanding and control of matter at the nanoscale, at dimensions between approximately 1 and 100 nanometers, where unique phenomena enable novel applications." 2 As in other countries, university education in the nanotechnology field in France has expanded very rapidly in recent years, from about 20 masters' programs in $2002^{3}$ to 90 in $2011^{4}$. The reason for this rapid expansion is that nanotech is not a new discipline, but rather an approach that promises to renew many scientific and technological

\footnotetext{
${ }^{1}$ The Bologna process is an intergovernmental initiative, now involving 46 European and non-European countries, who have all freely committed themselves (by signing the Bologna declaration of 19 June 1999) to harmonize their higher education systems. Among other reforms, these countries commit themselves to adopting a common degree structure, based mainly on undergraduate and graduate/masters level qualification. France began implementing the Bologna process in 2002.

${ }^{2}$ Source: U.S. National Nanotechnology Initiative: http://www.nano.gov/

${ }^{3}$ Source: "nanotechnology in French higher education", unpublished source from "micro and nanotechnology club" (professional association in the field), September 2002

(http://clubnanomicro.asso.fr/documents/nano_mont.pdf).

${ }^{4}$ Source: the magazine, L'Etudiant.
} 
fields (such as physics, chemistry, biology, optics, electronics): its advocates expect nanotechnology to "penetrate the education system in the next decade in a similar manner to how the microscopic approach made inroads in the last forty to fifty years" (Roco 2002 p.490). In the field of nanotechnology, the potential tensions between compliance, negotiation and self-determination, which we found characteristic of the engagement of French academics in curriculum change, seem to be exacerbated, making it an interesting setting for analyzing academics' strategic behavior in change situations.

First, nanotechnology represents a strategic issue for both universities and engineering schools, putting pressure on departments to develop training in this area. Because of the high cost of nanotechnology instruments, and also of the multidisciplinary nature of the field, this institutional pressure may be associated with obligations for academics to engage in collaboration with other university departments or research institutes, for joint courses or fund-raising. But at the same time, academics are often considered as pro-actively shaping the development of education in nanotechnology. Indeed, although nanotechnologies form part of a range of tools increasingly required by engineers (Chang and Freeman 2008), they do not necessarily correspond to clearly identified industrial needs: thus demand for nanotechnology curricula has been mostly driven by academics - seeking professional opportunities to train students for their research activities - rather than by firms. Moreover, nanotechnology does not fit straightforwardly into existing training models because of its multidisciplinary nature, so course design requires some creativity to set priorities and find the most appropriate approach to interdisciplinary education: "The field is currently in its infancy and is incredibly broad, spanning chemistry, physics, biology, mathematics and engineering. How do you possibly teach all these areas to students in a four-year honours degree? The simple answer is - you don't." (Shapter et al. 2002 p.513). Because of the potentially contradictory strategies involved in each change situation, case studies appeared to be a particularly relevant approach to capture the very diverse ways in which academics engage in nanotechnology curriculum change, and to identify those actions which show them behaving more or less strategically.

\section{2. Data collection}

We investigated (in 2010-2011) 20 post-graduate programs created between 2002 and 2010 at three French university campuses. We chose campuses situated in the three French regions with the highest nanotechnology research profiles: Region 1 (with 2,800 tenured and nontenured staff involved in nanotech research), and Regions 2 and 3 (each with approx. 1,000 tenured staff similarly involved $)^{5}$. Like most French campuses, those we studied housed several universities, engineering schools and research institutions, often offering joint masters' and doctoral programs.

We tried to capture the diversity of nanotechnology master programs: in terms of specialties (electronics, materials, physics, chemistry, biology); of institutions ( 8 university programs, 3

\footnotetext{
${ }^{5}$ Source: C'Nano, national network that federates all the French academic teams conducting research in nanotechnology.
} 
programs run by engineering schools, 9 joint-curricula courses run between universities and engineering schools); and finally of training objectives (research- or vocational-oriented programs ${ }^{6}$ ). While the departments we investigated also showed some heterogeneity in size and in academic recognition, all hosted active nanotechnology research activities, and had dedicated equipment and funding. With the exception of one doctoral program, the programs we studied were all at the masters' level, intended for post-graduate university students, or for engineering school students (whose diploma is the equivalent of a master's).

We conducted 35 interviews with associate or full professors in charge of these masters' programs (one interview for the smaller programs - those with an average of 20 students - and two for the larger ones, with 40 to 60 students enrolled). The interviews concentrated on the programs' origins and evolution, the motivation levels of those taking part, the obstacles academics encountered and the help they received in designing those programs. Conducted in French, the interviews lasted about 60 to 90 minutes, and were recorded and literally transcribed ${ }^{7}$. We supplemented this data by collecting and compiling extensive secondary documentation (information brochures, Education Ministry accreditation documents, course lists and academic staff, and statistics about students' subsequent placements).

\section{3. Data analysis}

Interview data were coded with NVivo software (part of the Computer Aided Qualitative Data Analysis Systems (CAQDAS) family) which supports both the coding process and data retrieval, increasing the rigor of the analysis in line with the inductive approach of our research. Coding was conducted in three stages ${ }^{8}$. First, we openly coded the transcripts according to the main themes that emerged inductively from the interviews, which covered both the curriculum change (the more or less innovative character of the program; its general vision, its content and organization; student enrolments); and academics' engagement in it (identifying project leaders; how they dealt with funding issues; how they handled the ministry's and the CTI's accreditation process; what obstacles/assistance they encountered/received from departments and/or universities; which collaborations with academics and industrial partners they built to achieve curriculum change).

In the second stage of our coding process, we searched for conceptual categories to interpret our coded material, and to analyze academics' modes of action in creating their nanotech curricula. Inspired by the literature on organizational change in higher education, we began by using Oliver's typology (1991) but - as other authors (Huisman and Meek 1999) had - we encountered the difficulty of characterizing curriculum change situations as involving a single - more or less pro-active - strategy. For instance, academics creating the nanomaterials master's program in Region 1 imposed a vision for their program $^{9}$, a strategy that can be

\footnotetext{
${ }^{6}$ There are currently two kinds of master degrees in France: research-oriented ("master recherche"), and vocational-oriented ("master professionnel").Some master programs are both research- and vocational-oriented. ${ }^{7}$ See the table of synthesis, annexed below (Table 2). Our interview records indicate the location, and the main scientific orientation of the programs involved in this study.

${ }^{8}$ Table 1 in the Annex gives an extract of the coding. Because of space limitation, we do not reproduce the entire coding for this interview, and have removed any double coding.

${ }^{9}$ See table 1 in annex
} 
interpreted as 'manipulation'. On the other hand, they developed a very structured normative discourse as to what a nanotechnology training course should consist of (multidisciplinary, international, being open to experimentation), and also adhered to European norms for enrolling students - so displaying a more compliant approach. In other curriculum change situations, academics - while being very constrained as to their actions - nevertheless insisted on their capacity to avoid obstacles (by 'recycling' a previously refused project, or by working with reduced means). We found that the academic project leaders all employed - to varying degrees, and depending on the type of actions they undertook - at least two different strategies (e.g., 'compliance' and 'manipulation', or 'manipulation' and 'compromise').

Therefore, at our third data analysis stage, we looked for other concepts that would reflect the various strategies adopted by academics engaged in curriculum change - the bricolage lens appeared to us as particularly illuminating for this purpose, for the reasons outlined above. We first verified that our interview material fitted this concept well, thus confirming its relevance for our study. We realized that the bricolage-activity undertaken by academics for curriculum change can be split into two types of actions, for which academics can adopt distinct strategies. The global conception of curriculum change (in particular, the vision for the program, and the identification of colleagues potentially interested in the project), can be interpreted as establishing the range and availability (the 'repertoire') of existing resources that may be useful, while the concrete structuring of the curriculum (in particular of its programs and their content, but also of organization, budget, student enrollment factors) resembles the aspect of assembling resources according to specific rules or norms ${ }^{10}$. Analyzing academics' engagement in curriculum change along these two dimensions, we differentiated three forms of bricolage activity from the 20 situations studied, each realized for a common type of curriculum change, which we observed on many campuses, with no significant regional differentiation ${ }^{11}$.

In what follows, we first show that the engagement of academics in curriculum change falls within the 'bricolage' regime of action (3.1), and then present the three forms of bricolage we encountered in our study, and describe the associated strategies ${ }^{12}$ (3.2). We categorized four of the 20 situations as 'crafting a specialized product', where the academic teams were highly pro-active in identifying international repertoires that enabled them to meet their visions, but which complied with specific rules of assemblage. In contrast, academics in charge of six other programs created new curricula by 'amalgamating' existing ones, identifying sets of useful resources by adopting a 'compromise' strategy between the demands made by various stakeholders, but also pro-actively 'manipulating' some expectations about the specific content of those programs. Lastly, we identified ten programs as examples of academics

\footnotetext{
${ }^{10}$ Some factors affecting curriculum change (such as institutional support or lack thereof, see table 1) may orient one or the other actions involved in bricolage activity, whether they relate to the general project or to its specific content.

${ }^{11}$ We found no examples of 'manipulation' strategy being used in Region 1 . However, a project which was under negotiation at the time of our interviews (and which we do not analyze here for this reason) shared some similarities with this ideal-type.

${ }^{12}$ For each bricolage form, we illustrate both types of actions with quotations that are particularly representative of the main actions undertaken by academics leading the curriculum change. (Quotations were translated into English by the author.)
} 
'renewing' curricula at the margin: in these cases, even though their level of resources at hand may have been severely limited by budgetary constraints or institutional directives, they were still able to display pro-active strategies in composing their programs.

\section{Results}

\section{1. Academics' bricolage activity for curriculum change}

As in other training areas, drawing up a nanotech master's program can be seen as a bricolage activity. First, academics rely on a collective 'repertoire' of existing courses, available equipment and other resources, funding, departmental support, and existing academic contacts - above all on knowing which colleagues could teach which course - so this repertoire is mostly constituted through "network bricolage" (Baker et al 2003 p.265). Rather than being predetermined, the design of the new program is likely to evolve gradually as actors get included through "network bricolage" and as they interact with each other. Academics' dependence on their existing professional networks is all the more important in nanotechnology program initiatives, as financial constraints mean such curricula can rarely be completely created from scratch. Moreover, as industrial needs are not clearly defined, and as teaching programs cannot cover all the research arenas of this expanding field, academics have considerable discretion in designing potential new courses, and in reusing resources they may have acquired for other purposes (e.g., for their research activity) - which directly reflects the notion of the resources used in bricolage as having "low functional fixedness" (Duymedjan and Rüling 2010 p.143-144). Second, the pedagogical structure of a whole course program can be seen as an assemblage, the value of which derives as much from the complementarity of its elements as from the intrinsic quality of any one of them - which is why such courses often offer students several modules to choose from. Drawing up such an assemblage is a creative activity: the rules for assembling or substituting elements are vague, its final configuration is likely to be modified through trial and error processes, and above all its success can only be evaluated ex post facto, perhaps only after several years, and largely through graduates' placements.

The creativity involved in such curriculum design is perhaps particularly apparent in nanotechnology, given that its multidisciplinary nature leads to many possible course combinations. But it is also subject to several types of constraints, some of which are common to all degree programs that fall within the same regulatory framework (e.g. the number of ECTS credits for countries adhering to the Bologna process); others - such as budgetary limitations and institutional policies - which vary from one situation to another. Creativity in course design is also subject to certain 'conventions' - such as the length of classes, the balance between practical courses and general lectures, the length of internships which make coordination and collective action practicable (Becker 1982).

Beyond this general description, our study also established that the bricolage activities undertaken for curriculum change took three forms, which could be differentiated by the more or less pro-active strategies academics followed for the two main bricolage actions: delimitating their repertoires of resources, and assembling the courses available from those 
repertoires into their final program designs.

\section{2. Three forms of bricolage}

\section{2. 1. Crafting a specialized product}

This first form of bricolage was observed in four European programs: three masters' programs run under the 'Erasmus Mundus' label ${ }^{13}$ and one European Summer School for doctoral students. The creation of European programs - and thus the Europeanization of French programs - has become increasingly frequent, and illustrates the French tendency to internationalize its higher education system. These four programs were specifically created to attract students and their potential employers to a specialized product that would be clearly identified as such in the international higher education market.

We found that academics involved in crafting new, specialized products displayed 'manipulation' strategies, or high levels of pro-activity with their environments, in identifying their international repertoires of existing resources and in overcoming local obstacles to their projects. Each program was entirely designed by a small team of academics from a single university, who approached foreign colleagues they knew well (who were or had been involved in the same research projects, or sat on the same $\mathrm{PhD}$ committees):

\footnotetext{
"Yes, we are basically people who know each other ... academics, but let's say we started out as a set of people at the leading edge of research. [...] Behind all that there were some big names... colleagues, people I know, people I consider to be right at the top and then, well... they themselves became coordinators, proposing other contributors." (Region 1- nanomaterials program)
}

These teams started from the rather vague project idea of creating world-class nanotechnology programs with the most famous experts in the field, which were gradually refined and realized by sharing courses, expertise, equipment and students. After many interactions, they designed end-products that would not only offer students specialized, leading edge research, and a highly-prized set of technological skills for the world of industry, but also - and above all - a 'package' of course elements which enhanced the value of their technological specialization: international mobility, entrepreneurial culture, and training in risk management. The progressive design of these projects through international network bricolage appears very close to the "continual accretion of inputs that progressively shaped the emerging paths" (Garud and Karnøe 2003 p. 294) described in other bricolage settings.

We found such international network bricolage allowed academics to bypass local obstacles to the realization of their projects, such as the lack of legitimacy of multi-disciplinary training in the eyes of their university colleagues, or the lack of logistical and financial support from their universities for developing international degree programs.

“A multi-disciplinary master's, it's a bit off the beaten track, it is not considered as good as a disciplinary master's... The international side does not necessarily make everyone happy, and I know for example that

\footnotetext{
${ }^{13}$ The EU awards this label to European joint Masters and Doctorates, Partnerships with non-European higher education institutions, and Projects to promote European higher education worldwide. Source: http://ec.europa.eu/education
} 
there are professors in some Parisian universities who prevent their students from going on our program." (Region 1- photonics program)

The Erasmus Mundus label represented an effective lever in helping these teams obtain additional resources from their own institutions:

"We started the masters' before getting the Erasmus Mundus label, and without additional resources from the university. An assistant professor made the website [and] I was allowed 30 hours per year to run an international masters'. Everyone says it's important to go international, but so what? Nothing at all. Yes, I have a part-time secretary, who is full of good will. Fortunately, we finally got the Erasmus Mundus label which will give me a salary to hire a manager." (Region 1- nanomaterials program)

At the same time, the rules for program composition constrained these academics, leading them - to some extent - towards an attitude of 'acquiescence'. They had to respect strict rules to get their international master's programs accredited by the Higher Education ministry, and achieving the European Erasmus label introduced further constraints, in that opportunities to associate and substitute courses were limited by the need to harmonize timetables, teaching methods and grading systems between participating countries. Programs had to follow some taken-for-granted values, such as the need to educate future nanotech leaders - researchers and engineers - in humanities.

\section{2. 2. Amalgamating existing elements}

This second form of bricolage was observed in six of the programs we studied, which were essentially created by the bricolage activity of amalgamating dispersed courses and other available resources on one or several campuses (either within or between departments physics, chemistry, electrical engineering, life-sciences - and even across institutions in some cases). This type of curriculum change is becoming increasingly common with the strengthening of inter-institutional collaborations on French campuses, and is generally encouraged by university managers. In these cases, academics tried to impose a certain order on the existing pedagogical landscape so as to make their programs more visible and attractive for students and their potential employers, and also to economize on teaching costs. Such programs typically covered wide nanotechnology fields (in terms of disciplines, technologies or domains of application), from which students could choose a specialty.

As in the previous mode, we found that each program was driven by a team of academics who were highly motivated to 'do something ambitious together', but without having any precisely preordained project design. They employed 'compromise' strategies to delimit the scope of the local resources on which they relied, trying to reconcile plural interests and meet multiple expectations - especially those of university managers, who they encouraged to see their projects as showcases for their institutions, and so provide additional funding.

\footnotetext{
"At the start, the idea was that 'we must federate, we must do something together', it was clearly a situation, I would say, of me and my colleagues acting as 'worker bees'. We said 'let's start something really ambitious'. The university immediately saw that this program really could be a showcase, they have supported us with financial resources, personnel, etc., which they might not have done for other masters'." (Region1 - nanosciences program)
}

This university support was greater in settings where the Higher Education Ministry had 
started giving institutions on the same campus financial incentives to cooperate (for example by them establishing a PRES ${ }^{14}$ or, more recently, by encouraging them to apply jointly to highly competitive calls for tenders ${ }^{15}$ ).

"The creation of the masters' course has clearly been pushed by our institutions. It is completely in line with what is currently being set up on the campus." (Region 3 - nanosciences program)

In this bricolage form, academics' repertoires were mainly local, but were still scattered across departments and institutions, so locating the relevant teaching modules represented a major effort:

"When we went round to the different establishments, I have to say - curiously, but it's true - that we never discussed the whole thing together (...) the seven establishments said 'well, yes, from our side we are prepared to make a deal on this or that lab-work, to contribute to the masters"'. So we made index cards of all this, with details of different components of lab-work so we came to realize, very quickly - before we had worked out our whole degree scheme - that we could offer some really good lab-work." (Region 1 nanosciences program).

In these cases, network bricolage formed part of a 'give-and-take' interplay between local constraints. However, cooperation problems between normally competing disciplines, departments or institutions tended to limit the scope of resources available nearby, and responses displaying attitudes such as 'robbing Peter to pay Paul'; and 'keep off my patch!' were common. Potential assemblages between courses inevitably required compromises academics designing collaborative course were likely to be subject to contradictory pressures between the incentives to mutualize resources and develop common strategies between institutions located on the same campus, and the desires of those institutions to maintain their autonomy.

"Depending on the call for tenders, etc., there were ups and downs. Before summer, collaboration was clearly at low ebb, the PRES was an empty shell, nothing was happening there. There was a shift this summer, when the ministry said a lot of money would go through the PRES. And of course the university presidents are no longer claiming 'We are independent'. So now we collaborate all-out." (Region 3 nanosciences program)

But at the same time, we found academics used 'manipulation' tactics to assemble courses into concrete programs. Their pools of resources were likely to be large enough to test different types of combinations, and the rules underpinning the structures of such new degree courses were less restrictive than those governing international master programs (especially those under the Erasmus Mundus label): for instance, there were no rules about how international a program should be, or the balance of human and social sciences it should contain. Finally, these new curricula covered broad fields, in which all sorts of different combinations might be equally valid, so new conventions could be established - between the core program and elective courses; between disciplines and multi-disciplinary elements; or between fundamental sciences and applied technologies. These programs did not yet have the prestige of the traditional disciplines - but, in fact, that allowed their academic designers a comparative degree of freedom, so they could still attract students by showing high degrees

\footnotetext{
${ }^{14}$ Created in 2006, the PRES (Pôles de Recherche et d'Enseignement Supérieur) are intended to regroup higher education and research institutions in France into large units, often by regrouping institutions in the same geographic areas.

${ }^{15}$ Such as those gathered under the Ministry's label "Initiative for Excellence", launched in 2010.
} 
of pedagogical innovation:

"Hence the idea of pushing multi-disciplinarity through research and laboratory work. The idea probably took form in the head of XX. There were no examples of this elsewhere, but it was a widespread idea in the university community. So three courses were cancelled in the first semester and replaced by work in the laboratories. The students work in pairs and spend three and a half days per week over one month in a laboratory." (Region 2 - nanosciences program).

\section{2. 3. Renewing existing programs}

This last form of bricolage applied in ten of our sample cases, where already existing programs were updated by the addition of some nanotechnology modules, which effectively served to reinforce the subjects already taught, and (as far as possible) were delivered by existing staff. This type of curriculum change is probably the most frequent - albeit the least visible - on French campuses.

In this bricolage form, we found academics meeting vaguely defined expectations (such as retaining their existing identities and the positions they already occupied in the higher education marketplace) without having concrete guidelines on how to meet them. The impetus for curriculum change may come from university managers or from the groups of academics themselves - in either case they relied on repertoires of scarce local resources to refresh their teaching programs. Constraints on the existing resources for curriculum change differed considerably in nature and intensity between research- and vocational-oriented master programs. The former programs rarely had sufficient funding to fight against students' disaffection for research training and academic careers, and academics running such programs saw nanotechnology as a way to demonstrate how innovative their training was, to attract more students and so retain their Ministry accreditation. But introducing nanotechnology is expensive (the hourly cost of renting nanotech lab space can be 10 to 20 times the average), and such financial barriers explain why such renewed programs typically only involved minor changes, mainly concerning lectures rather than lab-work:

"Lab-work raises financial problems. We have 2 Euros per hour of lab-work per student - we are not an engineering school, we are a university, so we have 2 Euros per student. So we cannot set up really cuttingedge lab-work." (Region 3 - nanomaterials program)

As entry into the first year of French university masters' courses is non-selective ${ }^{16}$, academics in such situations can be victims of their own success: if their 'refreshed' programs attract too many students, they may face a shortage of resources, in terms of sufficient space, equipment, and available staff to supervise students' studies:

"This year funding voted by the university has gone down, but student numbers have gone up - in particular, in the first year of the Masters', we have gone up from 30 to 48 students, and last year in the third year of the Bachelor's (Licence), we went up from 32 to 48. Engineering schools fix the number of their students and that's fine. But we can't do that; the law won't allow it." (Region 3 - nanomaterials program).

But academics did not generally face the same level of budgetary limitations on setting up

\footnotetext{
${ }^{16}$ All graduates from first degree courses (Licences) are freely admitted to the first year of all masters' programs in the same specialty, but entry into subsequent years is selective.
} 
interesting new courses in vocational masters' programs. Such programs were offered by both universities and/or engineering schools in partnership with industry - which could mitigate financial constraints, as firms might provide (for example) access to the equipment needed for lab-work. Engineering schools had more room for maneuver than universities (notably because of their higher per capita budgets). However - as in all professional-oriented curricula - collaboration with industry came with strings attached: all the changes academics envisioned when redesigning their programs had to be directly useful in supporting future industry needs:

"In life-sciences research, they use data modeling from microelectronics, which could open our program to other themes. That's really interesting, but in training, it is not obvious, because this is very transverse, and we cannot make exotic formations, because we do not want to put people on the labor market who then cannot find jobs." (Region 2 - nanoelectronics program)

But in both research- and vocationally-oriented curricula, academics retained a certain leeway and the chance to be pro-active in assembling courses into new programs. Where budgetary limitations meant certain combinations of course content or modules had to be excluded from research-oriented curricula, academics still managed to find some acceptable 'compromises' between those constraints and their professional interests, for example by moving lab-work from classrooms to their research labs, where equipment was available, so allowing lecturers to associate the courses directly with their research activities:

"All master students come to our research group for lab-work that seems important in the field of nanotechnology, and for which we have equipment, such as electronic microscopy. Researchers supervise students on a voluntary basis." (Region 3 - nanophysics program)

"Each research group is in charge of one course which is more or less appropriate to its research." (Region

3 - nanoelectronics program).

In some cases, academics teaching vocational-oriented courses employed 'avoidance' strategies when composing their programs - they maintained "nonconformity behind a façade of acquiescence" (Oliver $1991 \mathrm{p} 154$ ) by introducing a few nanotechnology courses - so benefiting (at little cost) from the attractiveness of the 'nano' label to students and employers - but without really changing the core focus of their teaching significantly:

“It's rather like lark pâté. You know, it contains 95\% pork and 5\% lark, but it's called lark pâté. If you take technological courses, you now have $95 \%$ of basic training, good basic physics, good basic technology, etc. I'm being a bit harsh in saying 5\%, but let's make it $80-20$; yes, that's it: $80 \%$ basic and $20 \%$ nanosomething or other." (Region 2 - nanophysics program).

\section{Conclusion}

This article adopts the notion of bricolage to analyze academics' actions when engaged in curriculum change initiatives. Widely used in organization theory (Baker et al. 2003, Garud and Karnøe 2003; Baker and Nelson 2005; Duymedjian and Rüling 2010; Odin and Thudéroz 2010) to analyze diverse situations where actors produce creative solutions from the resources they have at hand, without following any predetermined plan, the bricolage concept appears useful for understanding how - rather than under which conditions or in what contexts - academics act as central agents of organizational change, and in which kinds of 
actions they display more or less strategic behaviors.

We first show that curriculum change can be broadly analyzed as a bricolage activity composed of two types of actions: academics identifying a repertoire of resources (existing courses, academic colleagues, equipment, financial and institutional support, and reputational assets) located in their existing professional networks; then designing their programs by assembling courses, trying them out in various combinations, with the elements of their repertoire becoming valuable in the new course context once they are associated with each other.

We also find that the 'bricolage' regime may take several forms, depending on what strategies academics employ as they engage in these two dimensions of bricolage activity. Examining the creation of 20 new masters' nanotechnology programs, we identified three forms of bricolage: the crafting of a specialized product; the amalgamation of existing courses; and lastly, the reorientation of existing curricula. In all three situations, academics expressed mixed feelings about their bricolage activity, sometimes claiming it as an expression of their professional autonomy vis-à-vis the university management (justified by their mobilization of their colleague networks), and sometimes also as a source of pride, in that it demonstrated their adaptability and flexibility, and their capacity to retain the ability to pursue their own objectives in the face of budgetary constraints or institutional directives. But at the same time, they noted that bricolage could be a time-consuming activity - requiring many interactions between participants in their bricolage networks, as well as several rounds of experimenting with different assemblages to achieve their final project designs - as well as a frustrating one - because of the lack of clear guidelines for designing new programs, and the difficulty of knowing when to stop the bricolage exploration process (Senyard et al. 2010 p.5).

The 'bricolage' concept allows us to use the strategies defined in Oliver's (1991) typology to analyze academics' actions during organizational change in higher education. By distinguishing between several activities in which they display more or less pro-active strategies, it helps to resolve a problem that arises when this typology is applied to overall situations - namely the coexistence of contradictory strategies. We show that several forms of agency, and several different styles of relationships to norms, can be associated with each curriculum change situation: not only because academics are situated in several institutional environments, and are subjected to institutional pressures which differ in nature and intensity - and may even be contradictory - but also because, from a practical point of view, they engage in different types of activities in transforming higher education delivery. We found academics' levels of proactivity varied considerably, both in terms of how they identified their repertoires of resources, and in how they built their idiosyncratic resource combinations (Baker and Nelson 2005 p.356).

Crafting a specialized product reflected academics' desire to situate their programs to appeal to the European market as their top priority, freeing themselves from the influence of local institutions, adhering instead to more demanding international competition norms. However 'manipulative' their strategies may seem when identifying their strengths, they clearly obeyed (more or less consciously) taken-for-granted international rules or values (be they of the 
European commission or of the international higher education market) - when assembling courses into their new programs. In contrast, the amalgamation of existing courses demonstrated the use of strategies of 'compromise' within and between several local higher education departments or institutions. Here, both the identification of existing resources and their assemblage seemed heavily constrained by local politics (negotiation of interests between academics, changes in support by university management, differences in attitudes towards inter-institutional cooperation). However, where the participating institutions shared no clear course model, academics used strategies of 'manipulation' of the "definitions and criteria of acceptable practices or performance" (Oliver 1991 p.158) in drawing up their course programs, demonstrating their freedom to indulge in pedagogical experimentation. Finally, the renewal of degree programs was a good example of academics suffering from a shortage of resources at hand to change their curriculum. But, however constrained (and sometimes insecure) this might make their projects, they still managed to maintain their professional autonomy when composing their programs, whether by adopting 'compromise' strategies to find ways to satisfy both institutional requirements and professional interests (in the case of research-oriented curricula), or by developing strategies of 'avoidance' and 'window-dressing' their courses (as when vocational-oriented curricula were relabeled 'nano', but retained almost the same content).

Finally, there are various ways in which our findings could be extended. First, the notion of 'network bricolage' - the idea that academics find means at hand from their existing networks of contacts - draws our attention to how academics can mobilize those networks for achieving (or influencing) organizational change. We observed several forms and scopes of such networks (international vs. local; research-oriented vs. teaching-oriented; dispersed vs. compact). This analysis could be systematized and made more dynamic by investigating the links between changes in academic networks (becoming more international, more connected with industry (Grossetti and Milard 2003), or more multidisciplinary), and the mechanics of curriculum change in higher education. Our observations also revealed that academics can refer to some norms rather than others, and how, by so doing, they contribute to the reproduction and the transmission of certain pedagogical models and higher education 'missions' (such as the professionalization of students; the internationalization of curricula; the promotion of multi-disciplinary training, particularly in terms of introducing social sciences courses into science curricula; the balance between lectures, lab-work and tutorials; the relationships between faculty staff and students; and the balance between academic and industrial imperatives). Further work could analyze more precisely how academics designing new curricula contribute, through their bricolage activity, to the local adaptation of such norms. We argue that such efforts would reveal bricolage as one of the most important practices structuring the "local translation of globalized models" (Mazza et al. 2005). 


\section{Annex}

Table 1: Coding extracts from interview with the Professor who initiated the Region 1 nanomaterials masters' program

\begin{tabular}{|c|c|c|c|c|}
\hline \multirow{2}{*}{\multicolumn{2}{|c|}{ Stage 1: Inductive coding }} & \multirow{3}{*}{$\begin{array}{c}\text { Stage 2: } \\
\text { Corresponding } \\
\text { strategy in } \\
\text { Oliver's } \\
\text { typology } \\
\text { Manipulation }\end{array}$} & \multicolumn{2}{|c|}{$\begin{array}{c}\text { Stage 3: Redefinition of academics' engagement as a } \\
\text { bricolage activity, and description of the two main actions } \\
\text { involved }\end{array}$} \\
\hline & & & \multirow{2}{*}{$\begin{array}{l}\begin{array}{l}\text { Identification of repertoire of } \\
\text { resources }\end{array} \\
\text { Manipulation: selection of possible } \\
\text { courses according to academics' } \\
\text { vision of the structuration of the } \\
\text { nanosciences. }\end{array}$} & \multirow[t]{2}{*}{$\begin{array}{l}\text { Assemblage of resources } \\
\text { according to certain } \\
\text { rules or conventions } \\
\end{array}$} \\
\hline $\begin{array}{l}\text { General vision } \\
\text { for the program }\end{array}$ & $\begin{array}{l}\text { "The other nanoscience masters' program on campus targets the } \\
\text { understanding of nano-phenomena, but is little concerned with } \\
\text { applications. Our approach is clearly the opposite ... I wanted it as } \\
\text { such from the beginning." }\end{array}$ & & & \\
\hline & $\begin{array}{l}\text { "We chose to specialize students in a few areas as our challenge, } \\
\text { rather than covering all areas superficially. Because if you } \\
\text { understand something thoroughly with rigorous reasoning, you can } \\
\text { renew yourself scientifically." }\end{array}$ & Manipulation & $\begin{array}{l}\text { Manipulation: selection of possible } \\
\text { courses according to academics' } \\
\text { vision of the evolution of research. }\end{array}$ & \\
\hline $\begin{array}{l}\text { Student } \\
\text { enrolment }\end{array}$ & $\begin{array}{l}\text { "The program is open to European students, but also students from } \\
\text { third-world countries, it is a [response to the] request from Europe } \\
\text { to compete with American universities, that's the outline of the } \\
\text { Erasmus Mundus program." }\end{array}$ & Acquiescence & & $\begin{array}{l}\text { Acquiescence } \\
\text { Reproducing European } \\
\text { model for higher } \\
\text { education }\end{array}$ \\
\hline $\begin{array}{l}\text { Content of the } \\
\text { curriculum }\end{array}$ & $\begin{array}{l}\text { "The program is really large, somehow multidisciplinary, but also } \\
\text { includes entrepreneurial tools designed to train future leaders. It is } \\
\text { essential to establish a difference from other formations." }\end{array}$ & Acquiescence & & $\begin{array}{l}\text { Acquiescence } \\
\text { Differentiation with } \\
\text { competing curricula } \\
\text { (response to market } \\
\text { constraints) }\end{array}$ \\
\hline $\begin{array}{l}\text { Key actors of } \\
\text { the curriculum } \\
\text { change }\end{array}$ & $\begin{array}{l}\text { "Yes, we are basically people who know each other... academics, } \\
\text { but let's say we started out as a set of people at the leading edge of } \\
\text { research. } \\
\text { It is a product we have constructed with colleagues from three } \\
\text { other European universities." }\end{array}$ & Manipulation & $\begin{array}{l}\text { Manipulation: Mobilization of } \\
\text { international research networks for } \\
\text { designing curriculum change } \\
\text { (network bricolage) }\end{array}$ & \\
\hline Institutional & "Recognition of this project by the university is zero. The & Manipulation & Manipulation: convincing the & \\
\hline
\end{tabular}




\begin{tabular}{|c|c|c|c|c|}
\hline \multirow[t]{2}{*}{$\begin{array}{l}\text { support (or lack } \\
\text { thereof) }\end{array}$} & $\begin{array}{l}\text { university trains } 1,000 \text { masters' students annually; its priority is } \\
\text { not to think internationally. I asked for an appointment with the } \\
\text { President to address this issue. What we are doing is the future." }\end{array}$ & & $\begin{array}{l}\text { management from the legitimacy of } \\
\text { international master programs } \\
\text { (attempt to change institutional } \\
\text { expectations) }\end{array}$ & \\
\hline & $\begin{array}{l}\text { "We started the master's before getting the Erasmus Mundus label, } \\
\text { and without additional resources from the university. (...) } \\
\text { Fortunately, we finally got the Erasmus mundus label that will } \\
\text { give me a salary to hire a manager." }\end{array}$ & Acquiescence & & $\begin{array}{l}\text { Acquiescence } \\
\text { Adoption of European } \\
\text { rules }\end{array}$ \\
\hline $\begin{array}{l}\text { Accreditation } \\
\text { process }\end{array}$ & $\begin{array}{l}\text { "These masters have the highest quality level in Europe. Why? } \\
\text { Because in fact they go through the mill of four accreditation } \\
\text { systems. And of course, the biggest mill is Europe." }\end{array}$ & Acquiescence & & $\begin{array}{l}\text { Acquiescence } \\
\text { Adoption of European } \\
\text { rules }\end{array}$ \\
\hline
\end{tabular}


Table 2 Synthesis of the empirical results for the 20 masters' programs analyzed

\begin{tabular}{|c|c|c|c|c|c|}
\hline $\begin{array}{l}\text { Form of } \\
\text { bricolage }\end{array}$ & Action & Strategy & $\begin{array}{l}\text { Degree programs } \\
\text { analyzed }\end{array}$ & Type of program & \\
\hline \multirow{4}{*}{ 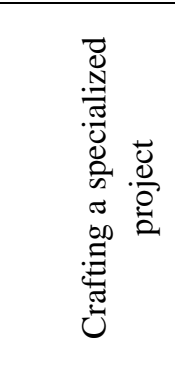 } & \multirow[t]{4}{*}{$\begin{array}{l}\text { Composing the } \\
\text { repertoire }\end{array}$} & \multirow{3}{*}{ Manipulation } & $\begin{array}{l}\text { Region 1- } \\
\text { nanomaterials }\end{array}$ & $\begin{array}{l}\text { Research and vocational program } \\
\text { Erasmus Mundus European label }\end{array}$ & $\begin{array}{l}\text { Join degree between universities \& non-university schools } \\
\text { Accreditation by the ministry }\end{array}$ \\
\hline & & & Region 1- photonics & $\begin{array}{l}\text { Research and vocational program } \\
\text { Erasmus Mundus European label }\end{array}$ & $\begin{array}{l}\text { Engineering school degree } \\
\text { Accreditation by the ministry }\end{array}$ \\
\hline & & & $\begin{array}{l}\text { Region } 2- \\
\text { nanoelectronics } 2\end{array}$ & $\begin{array}{l}\text { Research and vocational program } \\
\text { Erasmus Mundus European label }\end{array}$ & Accreditation by the ministry and by the CTI \\
\hline & & Acquiescence & $\begin{array}{l}\text { Region } 2 \text { - Summer } \\
\text { school }\end{array}$ & Doctoral program & No national habilitation \\
\hline \multirow{6}{*}{ 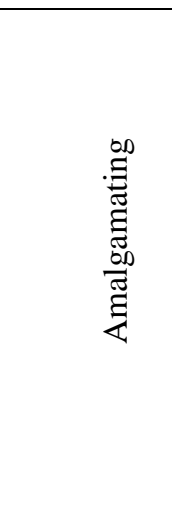 } & \multirow{3}{*}{$\begin{array}{l}\text { Composing the } \\
\text { repertoire }\end{array}$} & \multirow{3}{*}{ Compromise } & $\begin{array}{l}\text { Region } 1- \\
\text { nanomaterials }\end{array}$ & Research program & $\begin{array}{l}\text { University degree } \\
\text { Accreditation by the ministry }\end{array}$ \\
\hline & & & $\begin{array}{l}\text { Region 1- } \\
\text { Nanosciences }\end{array}$ & Research program & $\begin{array}{l}\text { Join degree between universities \& non-university schools } \\
\text { Accreditation by the ministry }\end{array}$ \\
\hline & & & Region 1 - nanophysics & Research program & $\begin{array}{l}\text { University degree } \\
\text { Accreditation by the ministry }\end{array}$ \\
\hline & \multirow{3}{*}{$\begin{array}{l}\text { Assembling the } \\
\text { resources }\end{array}$} & \multirow{3}{*}{$\begin{array}{l}\text { Compromise and } \\
\text { manipulation }\end{array}$} & $\begin{array}{l}\text { Region } 2- \\
\text { nanosciences } \\
\end{array}$ & Research program & $\begin{array}{l}\text { University degree } \\
\text { Accreditation by the ministry }\end{array}$ \\
\hline & & & Region 2 - platform & $\begin{array}{l}\text { Technological platform for training } \\
\text { purposes }\end{array}$ & \\
\hline & & & $\begin{array}{l}\text { Region 3- } \\
\text { Nanosciences } \\
\end{array}$ & Research program & $\begin{array}{l}\text { Join degree between universities \& non-university schools } \\
\text { Accreditation by the ministry }\end{array}$ \\
\hline \multirow{6}{*}{ 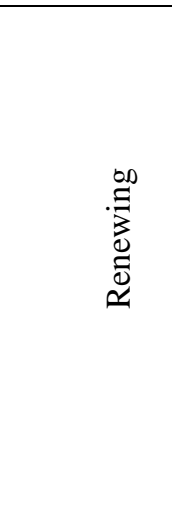 } & \multirow{6}{*}{$\begin{array}{l}\text { Composing the } \\
\text { repertoire }\end{array}$} & \multirow{3}{*}{ Acquiescence } & $\begin{array}{l}\text { Region } 1- \\
\text { nanomaterials }\end{array}$ & Vocational program & $\begin{array}{l}\text { University degree } \\
\text { Accreditation by the ministry }\end{array}$ \\
\hline & & & $\begin{array}{l}\text { Region } 1- \\
\text { nanochemistry }\end{array}$ & Research and vocational program & $\begin{array}{l}\text { University degree } \\
\text { Accreditation by the ministry }\end{array}$ \\
\hline & & & Region 3 - nanophysics & Research program & $\begin{array}{l}\text { University degree } \\
\text { Accreditation by the ministry }\end{array}$ \\
\hline & & \multirow{3}{*}{$\begin{array}{l}\text { Compromise or } \\
\text { avoidance }\end{array}$} & $\begin{array}{l}\text { Region } 3- \\
\text { nanoelectronics }\end{array}$ & Research program & $\begin{array}{l}\text { University degree } \\
\text { Habilitation by the ministry }\end{array}$ \\
\hline & & & $\begin{array}{l}\text { Region } 2- \\
\text { nanoelectronics }\end{array}$ & Research and vocational program & $\begin{array}{l}\text { University degree } \\
\text { Accreditation by the ministry }\end{array}$ \\
\hline & & & $\begin{array}{l}\text { Region } 3- \\
\text { nanomaterials }\end{array}$ & Research program & $\begin{array}{l}\text { Join degree between universities and engineering schools } \\
\text { Accreditation by the ministry and by the CTI }\end{array}$ \\
\hline
\end{tabular}




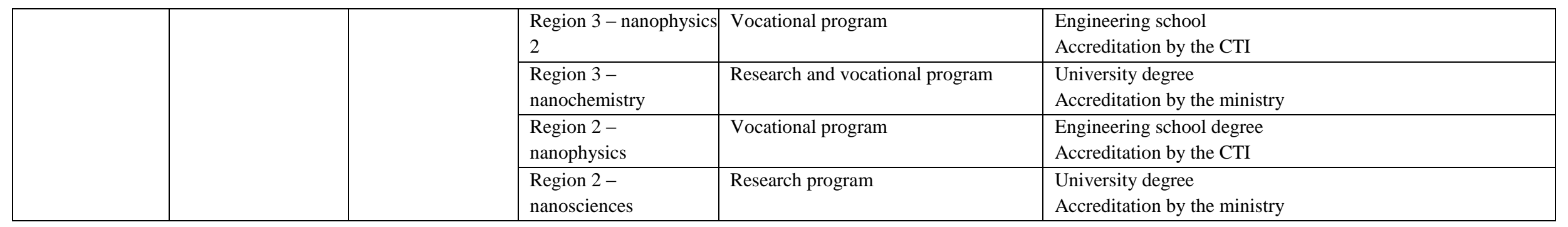




\section{References}

Amaral, A. (2008). Transforming higher education. In A. Amaral, E. Bleiklie, \& C. Musselin (Eds.), From governance to identity. A festschrift for Mary Henkel (pp. 81-94): Springer.

Baker, T., Miner, A. S., \& Eesley, D. T. (2003). Bricolage, account giving and improvisional competencies in the founding process. Research Policy, 32(2), 255-276.

Baker, T., \& Nelson, R. E. (2005). Creating Something from Nothing: Resource Construction through Entrepreneurial Bricolage. Administrative Science Quarterly, 50(3), 329-366.

Becker, H. (1982). Art worlds Berkeley: University of California Press.

Bleiklie, E., \& Michelsen, S. (2008). The university as enterprise and academic co-determination. In A. Amaral, E. Bleiklie, \& C. Musselin (Eds.), From governance to identity. A festschrift for Mary Henkel (pp. 5778): Springer.

Brint, S., Proctor, K., Hanneman, R. A., Mulligan, K., Rotondi, M. B., \& Murphy, S. P. (2011). Who are the early adopters of new academic fields? Comparing four perspectives on the institutionalization of degree granting programs in US four-year colleges and Universities, 1970-2005. Higher Education, 61(5), 563-585.

Brunsson, N., \& Sahlin-Anderson, K. (2000). Constructing Organisations: The Example of Public Reform Sector. Organisation Studies, 21(4), 721-746.

Chang, T., \& Freeman, R. (2008). Nanotechnology: recommendations for regional policy makers. Cambridge, Massachussets: Science and Engineering Workforce Project, National Bureau of Economic Research.

Clark, B. R. (1983). The Higher Education System : Academic Organization in Crossnational Perspectives. Berkeley: University of California Press.

Cohen, M. D., March, J. G., \& Olsen, J. P. (1972). A Garbage Can Model of Organizational Choice. Administrative Science Quartely, 17(1), 1-25.

DiMaggio, P. J., \& Powell, W. W. (1983). The iron cage revisited : Institutional isormorphism and collective rationality in organizational fields. American Sociological Review, 48(2), 147-160.

Duymedjian, R., \& Rüling, C. (2010). Towards a Foundation of Bricolage in Organization and Management Theory. Organization Studies, 31(2), 133-151.

Enders, J., De Boer, H., \& Leisyte, L. (2008). On striking the right notes: shifts in governance and the organisational transformation of universities. In A. Amaral, E. Bleiklie, \& C. Musselin (Eds.), From Governance to identity. A festschrift for Mary Henkel. (pp. 113-129): Springer.

Fumasoli, T., \& Lepori, B. (2011). Patterns of strategies in Swiss higher education institutions. Higher Education, 61(2), 157-178.

Garud, R., \& Karnøe, P. (2003). Bricolage versus breakthrough: distributed and embedded agency in technology entrepreneurship. Research Policy, 32(2), 277-300.

Gioia, D. A., \& Thomas, J. B. (1996). Identity, issue and image interpretation: sensemaking during strategic change in academia. Administrative Science Quarterly, 41(3), 370-403.

Grossetti, M., \& Milard, B. (2003). Les évolutions du champ scientifique en France à travers les publications et les contrats de recherche. Actes de la recherche en sciences sociales(148), 47-56.

Hardy, C. (1991). Configuration and Strategy Making in Universities: Broadening the Scope. The Journal of Higher Education, 62(4), 363-393.

Huisman, J., \& Meek, L. (1999). New study programmes at universities: Strategic adaptation versus institutional adjustment. In B. Jongbloed, P. Maassen, \& G. Neave (Eds.), From the eye of the storm; Higher Education's Changing Institutions. (pp. 121-140). Dordrecht: Kluwer Academic Publishers.

Jarzabkowski, P. (2008). Shaping strategy as a structuration process. Academy of Management Journal, 51(4), 621-650.

Leisyte, L., Enders, J., \& De Boer, H. (2008). The freedom to set research agendas: Illusion and reality of the research units in the Dutch Universities. Higher Education Policy, 21(3), 377-391.

Lévi-Strauss, C. (1966). The savage mind. Chicago: University of Chicago Press.

Maassen, P. (2002). Organisational Strategies and Governance Structures in Dutch Universities. In A. Amaral, G. Jones, \& B. Karseth (Eds.), Governing Higher Education: National Perspectives on Institutional Governance (pp. 23-41). Dordrecht: Kluwer. 
Maassen, P., \& Gornitzka, A. (1999). Integrating two theoretical perspectives on organizational adaptation. In B. Jongbloed, P. Maassen, \& G. Neave (Eds.), From the eye of the storm; Higher Education's Changing Institutions (pp. 295-316). Dordrecht: Kluwer Academic Publishers.

March, J. G. (1978). Bounded Rationality, Ambiguity, and the Engineering of Choice. The Bell Journal of Economics, 9(2), 587-608, doi:10.2307/3003600.

Mazza, C., Sahlin-Andersson, K. S., \& Strandgaard Pedersen, J. (2005). European Constructions of an American Model: Developments of Four MBA programs. Management Learning, 36(4), 471-491.

Meyer, J. W., \& Rowan, B. (1977). Institutionalized Organizations: Formal Structure as Myth and Ceremony. American Journal of Sociology, 83(2), 340-363.

Musselin, C. (2004). The long march of French Universities. New York: Routledge.

Odin, F., \& Thuderoz, C. (Eds.). (2010). Des mondes bricolés? Arts et sciences à l'épreuve de la notion de bricolage Lausanne: Presses Polytechniques et Universitaires Romandes

Oliver, C. (1991). Responses to institutional processes. The Academy of Management Review, 16(1), 145-179.

Reale, E., \& Seeber, M. (2011). Organisation response to institutional pressures in Higher Education: the important role of the disciplines. Higher Education, 61(1), 1-22.

Roco, M. C. (2002). Nanotechnology - A Frontier for Engineering Education. International Journal of Engineering Education, 18(5), 488-497.

Senyard, J. M., Baker, T., \& Steffens, P. R. (2010). Entrepreneurial bricolage and firm performance : moderating effects of firm change and innovativeness. Paper presented at the Annual meeting of the Academy of Management, Montréal

Shapter, J. G., Ford, M. J., Maddox, L. M., \& Waclawik, E. R. (2002). Teaching Undergraduates Nanotechnology. International Journal of Engineering Education, 18(5), 512-518.

Shore, C., \& Wright, S. (2000). Coercice accountability: the rise of audit culture in higher education. In M. Strathern (Ed.), Audit Cultures. Anthropological studies in accountability, ethics and the academy (pp. 57-89). London and New-York: Routledge.

Simon, H. A. (1972). Theories of Bounded Rationality. In C. B. McGuire, \& R. Radner (Eds.), Decision and organization (pp. 161-176). Amsterdam, New-York: North-Holland Publishing Company.

Townley, B. (1997). The institutional logic of performance appraisal. Organization Studies, 18(2), 261-285.

Weick, K.-E. (1976). Educational Organizations as loosely coupled systems. Administrative Science Quarterly, 2l(1), 1-19.

Witte, J. (2009). Parallel Universes and Common Themes: Reforms of Curricular Governance in The Bologna Context. In A. Amaral, G. Neave, C. Musselin, \& P. Maassen (Eds.), European Integration and the Governance of Higher Education and Research (pp. 227-255): Springer. 